\title{
LAND USE PATTERN, CLIMATE CHANGE, AND ITS IMPLICATION FOR FOOD SECURITY IN ETHIOPIA: A REVIEW
}

Hamza, I.A. ${ }^{1}$ and Iyela A. ${ }^{2}$

DOI: http://dx.doi.org/10.4314/ejesm.v5i1.4

Received $7^{\text {th }}$ December 2011: accepted $30^{\text {th }}$ January 2012

\begin{abstract}
Climate change is perhaps the greatest challenge facing the world today. In Africa, a continent which is and still remains vulnerable to the impact of climate change, the effects cannot be overemphasized in view of the already existing pathetic conditions of most developing countries in Africa. In Ethiopia, 85\% of the population is directly supported by agricultural economy. However the productivity of the economy is threatened by land use changes and unsustainable land management practices which had impacted seriously on Ethiopia's rich biodiversity, crop production and livestock grazing lands. While Ethiopia has always suffered from climatic variability like droughts and consequently food shortage and famine, climate change is set to make the lives of the poorest even harder. Climate change has the potential to adversely affect net farm revenues of small holders with increasing land fragmentation due to population growth translating to worsening food security situations. Since food security brings in additional socio-economics, geographical and political factors, focusing on measures of vulnerability, adaptation options and the development of adaptive capacity to reduce the adverse impacts of climate change in the rural areas of Ethiopia, this paper therefore reviewed the effect of climate change on land use pattern and the implication for food security in Ethiopia.
\end{abstract}

Key words: Climate change, Land use pattern, and Food security.

\section{Introduction}

Agriculture has been the mainstay of the economy of Ethiopia's economy, and will remain so in the foreseeable future. Until recently, Ethiopia's agriculture met nearly the food needs of the population, at least at the subsistence level. Agriculture provides about half of the gross domestic product (GDP) and 85\% of foreign exchange earnings of the country (Sonneveld, 2002). Almost $80 \%$ of the population lives in rural areas and depending on crop production and/or keeping livestock as means of livelihood. Livestock are a dominant feature of both crop production and pastoral agriculture, as well as the principal rural means of acquiring and holding wealth (Haile lul Tebicke, 1985). In the last three decades, Ethiopian agriculture has expanded dramatically, but not without the constraints arising due to massive land degradation occasioned by the natural topography as well as the increase in population, which has led to the expansion of agriculture into marginal lands. Most parts of arable lands in Ethiopia are prone to wind

${ }^{1}$ Department of Plant Sciences, Ambo University, Ambo, Ethiopia.

${ }^{2}$ Federal College of Education, P. M. B. 1026, Okene, Kogi State, Nigeria

Corresponding authorEmail:haiayi@yahoo.com and water erosion in the low and highlands areas. (Sonneveld 2002).

In 1984, an FAO (Food and Agricultural Organization) assisted survey of land use, using satellite imagery and ground checks shows that livestock grazing covers $51 \%$, rain-fed crop cultivation, $14.7 \%$, woody vegetation, $11.7 \%$ with one third of this covered by natural forest, while unproductive though potentially fertile land covers $3.8 \%$ and the remaining $18.5 \%$ of the land declared as unusable. The report also identifies excessive livestock population as the primary cause of land degradation in Ethiopia. Ethiopia is said to have the largest number of livestock in Africa (Berry, 2003.). Livestock density is beyond the carrying capacity of the grazing lands; consequently the competition for land is keen between livestock and crops. Apart from the constraints of land resources, Ethiopia has always experienced unstable climatic condition; rainfall varies from year to year, especially in the semiarid lowlands. A rising rainfall patterns in the late $70 \mathrm{~s}$ was interrupted by the drought of 1983-1984 (Daba, 2003). Prolonged droughts are a recurring 
but unpredictable hazard. Despite the frequency and severity of droughts in the past few decades, technologies such as improve varieties and irrigation water management techniques which have proved effective in mitigating the effect of droughts have not resulted to the desired level of outcomes in Ethiopia due to other socioeconomic related factors affecting the production process.

Food security revolves around complex issues that encompasses a wide range of interrelated environmental (and climatological), economic, social and political factors. In 2003, FAO defined food security as existing when all people, at all times, have physical, social and economic access to sufficient, safe and nutritious food to meet their dietary needs and food preferences for an active and healthy life. Devereaux and Maxwell (2001) defined food security as the success of local livelihoods to guarantee access to sufficient food at household levels. Agriculture has been identified by the food and agricultural organization (FAO) as having a vital role to play in food security. Ethiopia is largely agrarian, dominated by small scale farmers who employ largely rainfed and traditional practices - a state which renders Ethiopia highly vulnerable to climate variability (persistent drought in the past) and climate change. Climate variability and change are a major threat to food security in many regions of the developing world, which are largely dependent on rain-fed and labor-intensive agricultural production (Parry et al., 2004; IPCC, 2001a).

Food insecurity is an integral part of poverty in Ethiopia. Desertification, brought by human land use pressure and recurrent drought occasioned by climate change has consumed significant land area and continues to threaten arable lands that are already fragmented, thus threatening the source of income of the small scale farmer. Although several researches have been done on global warming and the impact of climate change on agriculture, not much emphasis have been directed towards land use pattern and change (Deressa et al., 2008; Garedew et al, 2009). Despite understanding the multidimensional nature of food insecurity, it remains a key concern affecting the livelihoods of marginal groups.

Therefore understanding the effect of climate change on land use pattern as well as its implication for food security is critical to looking for options to mitigate the impacts. This review will focus on the impact of climate change on land use change and implication on livelihood of the rural poor.

\section{Land use pattern, climate change and biodiversity}

Land cover refers to the physical and biological cover over the surface of the land. Land use and land cover change is a term used for the human modification of the earth terrestrial surface. Much of the world's natural land cover has been transformed by human activities (Morton et al., 2006), resulting in ecosystem degradation and biodiversity loss worldwide (Green et al., 2005). An estimated 4.7 million $\mathrm{km}^{2}$ of grassland areas and 6 million $\mathrm{km}^{2}$ of forest/woodland have been converted to cropland worldwide since 1850 (Lambin et al., 2003), and the main purpose for land use change is to obtain food and other essentials. In Ethiopia, land use can be seen from the perspective of human activities such as agriculture, forestry, building construction, and recently, industrialization which has led to increased human population within urban areas and depopulation of rural areas. The driving forces behind land use pattern include all factors that influences human activity, including local culture (food preferences), economics (demand for specific products, financial incentive), environmental condition (soil quality, terrain and moisture).

Land use change is largely driven by the decision of the people and population growth, declining household farm size and income. There have been many studies on land use and cover changes both at regional or local levels (Tsegaye et al., 2009; Garedew et al., 2009; Gete and Hurni, 2001), but most often they deal with quantifying land use/change using remote sensing tools, which give quantitative descriptions but do not explain or provide understanding of the relationship between the pattern of change and there driving forces (Olson et al., 2004). However studies linking land cover changes with drivers are scarce. In Ethiopia few attempts have been made outside the range land. Tsegaye et al., (2009) reported a rapid reduction in woodland (97\%) and grassland (88\%) between 1972 and 2007, while the size of cultivated land increased more than eightfold in the Northern Afar region. Similarly, Gete (2000) observed a reduction in forest cover in Central Gojam from $27 \%$ in 1957 to $0.3 \%$ in 1994 . The 
same trend was recorded in the western part of Ethiopia. Land degradation by overgrazing and intensive agriculture on marginal lands is a major cause of soil loss.

Ethiopia is a country with high biodiversity and distinctive ecosystem, and the natural resource base is critical to the economy and livelihood of a greater percentage of the population (Hurni, 1993). However rising population has increased pressure on land resulting in reduced farm outputs and increase demand for more agricultural land. When a land is transformed from a primary forest to a farm the loss of forest species is immediate and complete and indirectly affects wild life. Land use plays a major role in climate change at global, regional and local scales. It is responsible for releasing greenhouse gases, and the major driver of this change is deforestation and agriculture which causes the release of soil carbon in response to disturbance by tillage (Ellis, 2010).

In Ethiopia, biodiversity is an important resource having a dual purpose of utilization; consumptive use (food, fiber, fuel, shelter, medicine and wild life trade) and non-consumptive use (ecosystem services and economically important tourism industry). Given the heavy dependence of Ethiopia on natural resources, many communities are vulnerable to the biodiversity loss that could result additionally due to climate change. The use of fire as a management tool for slash-and-burn agriculture and other purposes results in at least a third of the savanna being burned every year (IPCC, 2000). Forest fires contribute to climate change and may result to significant ecosystem change that could affect biodiversity significantly. Land use pattern therefore contributes to global warming, leads to habitat conversions and fragmentation which directly impacts biodiversity. The impact of climate change on biodiversity would be further compounded by the climate induced alterations of agriculture (FAO, 1999).

\section{Land use effect on small holder production}

In Ethiopia crop production is increased recently through intensive and extensive agriculture systems. The intensification of agriculture and the expansion of croplands into marginal lands which is dominated by the traditional system/practices have led to severe land degradation (Hurni, 1988). Several studies have been done at the national level; the Highland
Reclamation Studies: Ethiopia (EHRS-FAO 1986), the National Conservation Strategy Secretariat (Sutcliffe 1993) and Ethiopian Forestry Action Plan (1993) all to estimate the level of land degradation. The studies show that, 30,000 ha is lost annually due to water erosion with over 2 million ha already severely damaged (National Review Report, 2002), United Nation Development Project in 2002 reported a nutrient depletion of $30 \mathrm{~kg} / \mathrm{ha}$ of Nitrogen and $15-20 \mathrm{~kg} / \mathrm{ha}$ of phosphorus, while a loss of 62,000 ha of forest and woodland annually have been reported by World Bank in 2001. All physical and economic evidence show that land degradation and the loss of land productivity is an important problem in Ethiopia, impacting on the rural livelihood.

Ethiopia is a country of small holder agriculture. In the year 2000 cropping season, $87.4 \%$ of rural households operated less than two hectares, $64.5 \%$ cultivated farms less than one hectare while $40.6 \%$ operated farm of less than 0.5 ha or less (Negatu, 2005), and such small farms were fragmented on average into 2.3 plots (Samuel, 2005). Therefore land holding is one factor that constrains farm income and level of household food security, especially where severe degradation has taken place. Such extremely small farms cannot be made productive with improved technology and certainly cannot improve the farmers' livelihood because of low net income thereby leaving no surplus for investment and input purchase.

\section{Impact of climate change on crop production}

Agricultural systems worldwide over the last $40-50$ years have responded to the effect of the interacting driving forces of population increase, income growth, urbanization, globalization on food production, markets and consumption (Von Braun, 2007). To these forces can be added the twin elements of climate variability and climate change which have a direct effect on food production and food security (Parryl et al., 2004). Ethiopia relies on rain-fed agriculture. As a result it is highly vulnerable to changes in climatic condition, seasonal shifts and precipitation patterns. Crop production and livestock husbandry account for about half of a household income, and the poorest members of the society are those who are most dependent on agriculture for jobs and income (FAO, 1999). The rural populace for whom agriculture is the primary source of direct 
and indirect employment would be most affected due to the vulnerability to global change processes (Ringler, 2008). Additionally the human alteration of land use patterns, elimination of wetlands and other biophysical changes could affect the water cycle ability to support the needed food production. Gregory et al., (1999) reported a decreased crop duration (and hence yield) of wheat as a consequence of warming and a reduction in the yield of rice of about $5 \%$ per ${ }^{0} \mathrm{C}$ rise above $32^{\circ} \mathrm{C}$. Using a simulation model of production for cropping systems, Tubiello et al., (2000) showed that the combined effect of increased carbon dioxide and climate change will depress crop yields by $10-40 \%$ if current management practices were not amended. Therefore new cropping systems which are resilient and adaptable to changing climatic conditions are required. More recently, elements of crop adaptation to extreme weather events have been explored with genotypic variation and adaptability to cope with several of the negative impacts on unadapted productivity (Fuhrer, 2006).

While Ethiopia has always suffered from great climatic variability, including droughts that have contributed to hunger, climate change is set to make the lives of the poorest even harder. Small scale farmers are more vulnerable and likely to bear the brunt of the negative impacts of climate change. This is partly due to the traditional management practices that they adopt. The expected crop yield losses due to climate change will therefore impact on their already low level of income, and left without any alternative source of income, the situation would lead to increased poverty and food insecurity.

\section{Climate change and food security implications} for Ethiopia

Food insecurity is an integral part of poverty in Ethiopia. At present agriculture dominates the Ethiopian economy, accounting for nearly half of gross domestic product (GDP), dominated by small scale farmers who employ largely rain-fed and traditional practices, therefore the consequence of land use change and the negative impacts of climate change will have a far reaching implication on food security. Desertification, brought on by human land use pressures and recurrent drought has consumed significant land area and continue to threaten arable land. Ethiopia has experience at least five major national droughts since 1980 (World Bank, 2007). Climate change is projected to reduce yields of crops like wheat by $33 \%$. Agro-pastoral and pastoral households, which are reliant on livestock for their livelihoods also suffer severe losses during droughts couple with seasonal reoccurring shortages due to diminishing grazing lands. This situation has forced some pastoral farmers to opt for crop production as reported by Tsegaye et al (2009).

Although Ethiopia has relatively abundant water, it has one of the lowest storage capacities in the world: 50 cubic meters per person (UNDP, 2007). Climate change is projected to cause the drying up of wetlands and run-off to Nile tributaries (Abay and Awash Rivers) would be reduced by up to one third (World Bank, 2007). These will have serious impact on the farmers' productivity due to water shortages.

One of the most strategically important issues in the context of environment - human relationship is the geography of insecurity in terms of resource availability and utilization; both latent (hidden danger) and realized (as currently being experienced in the form of conflicts among communities), posed by climate change. This has the potential to undermine the economic and political stability of some regions. An important question in this regard is "In which regions are the threats of climate change greatest"? Climate variability, specifically rainfall patterns resulting from climate change may result in decrease yield of crops. The reduction in crop yields may lead to higher prices for food, which could trigger regional food crises. These would lead to greater food insecurity causing political instability, increasing the stakes for control over productive agricultural land. Consequently, climate change by redrawing the map of water availability, food security and disease prevalence and loss of income source could increase forced migration, raised tensions and trigger conflict. Therefore the pattern of vulnerability to climate change on land use and food security is worrisome.

\section{Conclusion and Recommendation}

The review of the impact of climate change on crop production and implication for food security has shown that climate change will have a significant impact on biodiversity and food security in Ethiopia. Land use change is identified 
as one of the driving force for climate change, implicating agriculture and deforestation and intensive agriculture as causal factors. The vulnerability of the regions in Ethiopia would be determined by the level of exposure to drought and climate extremes, level of technology, socioeconomic and infrastructural development. There is the need therefore to mainstream climate change mitigation and adaptation into rural development process. Some practical steps for mainstreaming climate change will include setting aside existing bio-diverse habitats as conservation reserves, afforestation, avoidance of overgrazing, improvement in technology such as change in crop management practices and the encouragement of land use change in places where the threat of climate change makes the continuation of economic activity impossible or extremely risky such as returning cropland to pasture, forest or other uses may be found.

\section{References}

Berry, L. (2003). Land Degradation in Ethiopia: Its Extent and Impacts. A Pilot Case Study Analysis on Ethiopia Commissioned by the GM with WB Support, Pp 24.

Daba, S. (2003). An Assessment of the Physical and Socioeconmic Detriments of Soil Erosion in the Hararghe Highlands East Ethiopia, Land Degradation and Development, 14, 69-81.

Deressa, T., Hassan, R. M., and Ringler, C. (2008). Measuring Ethiopian Farmers Vulnerability to Climate Change Across regional States, IFPRI Discussion paper 00806.

Devereux, S, and Maxwell, S, Eds (2001). Food Security in Sub-Saharan Africa. London UK: Intermediate Technology Development Group Publishing

FAO, (1986). Highland Reclamation Study Ethiopia, Final Report Vol I and II, Rome, Italy.

FAO, (1999). The State of Food Insecurity in the World. Food and Agricultural Organization of the United Nations

Fuhrer, J. (2006). Agricultural Systems: Sensitivity to Climate Change, CAB Reviews: Perspective in Agriculture, Veterinary Science, Nutrition and Natural Resources, No 052.

Garedew, E., Sandewall, M., Sodaberg, U., and Cambell, B. M. (2009). Land Use and Land Cover Dynamics in the Central Rift Valley of Ethiopia. Environmental Management, 44, 683-694
Gete Zeleke. (2000). Landscape Dynamics and Soil Erosion Process Modelling in the North Western Ethiopian Highlands. African Study Series A 16. Geographica Bernensia, Berne, Switzerland.

Gete Zeleke and Hurni H. (2001). Implication of Land Use and Land Cover Dynamics for Mountain Resource Degradation in the North- Western Ethiopian Highlands. Journal of Mountain Research and Development, 21(2), 245 - 257.

Green, R. E., Cornell, S. J.,Scharlemann, J. P. W., and Balmford, A (2005). Farming and the Fate of Wild Nature. Science 307, 550-555

Gregory, P. J., Ingram, J. S. I, Cambell, B., Gourdriaan, J., Hunt, L. A.,Landsberg, J. J., Li nder, S., Stafford Smith, M., Sutherst, R. W., and Valentin, C. (1999). Managed Production Systems. In: Walker, B., Steffen, W., Candell, J, and Ingram, J. S. I.(eds). The Terrestrial Biosphere and Global Change: Implications for Natural and Managed Systems. Cambridge University Press, Cambridge, Pp 229- 270.

Hurni, H. (1988). Degradation and Conservation of the Resources in the Ethiopian Highlands. Mountain Research and Development, 8 (23), 123130

Hurni, H. (1993). Land Degradation, Famine and Land Resource Scenarios in Ethiopia. In: Pimentel, D., editor, World Soil Erosion and Conservation. Cambridge, UK, Cambridge University Press, Pp 27-61.

IPCC. (2001). Climate Change: Impacts, Adaptations and Vulnerability. IPCC Working Group II. 3rd Assessment Report ( McCarthy, J. J.,Canziani, N. A., Leary, D. J.,Dokken and K. S. White (eds), Cambridge University Press.

Lambin, E. F., Geist, H. J., and Lepers, E. (2003). Dynamics of Land Use and Land Cover Change in Tropical Regions. Annual Review Environmental Resource, 28, 205-241.

Mottet, A., Ladet, S., Coque, N., and Gibon, A. (2006). Agricultural Land Use Change Impacts in Mountain Landscapes: a Case Study in the Pyrenees. Agronomy, Ecosystem Environment, 114, 296-310

Olson, J. M., Misana, S., Cambell, D. J.,Mbonile, and Mugisha, S. (2004). Land Use Change Impacts and Dynamics (LUCID), Project Working Paper 48, International Livestock Research Institute, Nairobi, Kenya, Pp38. 
Parry, M. L., Rozenweig, C., Iglesias, A., Livermore, M., and Fischer, G. (2004). Effect of Climate Change on Global Food Production under SRES Emissions and Socioeconomic Scenarios, Global Environment Change, 14, 53-67.

Ringler, C. (2008). The Impact of Climate Variability and Climate Change on Water and Food Outcomes. IFPRI, Washigton D.C., U. S.A. Samuel G.. (2005).Recent experiences in land Rental markets in Ethiopia. Impact on Equity, Efficiency and Poverty. Paper Presented on Symposium on Land and Sustainable Development in Ethiopia, Organized by the FSS, EEA and AESE on August 5/2005, Addis Ababa. Sonneveld, B. G. J. S. (2002). Land Under Pressure. The Impact of Water Erosion on Food production in Ethiopia, Shaker Publishing, Netherlands.
Tsegaye, D., Farah, K. O., Mbuvi, D. M. (2009). Impact of Land Use on Vegetation Resources with Emphasis on Woody Vegetation in the Semi-arid area of Aba'ala District, North Afar Ethiopia. MSc thesis. Department of Range Management, University of Nairobi, Kenya.

Tubiello, F. N., Donatelli, M., Rozenweig, C. and Stockle, C. O. (2000). Effect of Climate Change and Elevated CO2 on Cropping Systems: Model Prediction, Environmental Journal of Agronomy, 13,179-189

UNDP. (2007). Fighting Climate Change. Human Development Report 2007/2008

Von Braun, J. (2007). The World Food situation: New Driving Forces and Required Actions. International Food Policy Research Institute, Washington D. C. USA.

World Bank. (2007). The Little Green Data Book. Washington.

Table 1 Estimated gross soil loss by land cover type in Ethiopia

\begin{tabular}{llll}
\hline \multicolumn{1}{c}{ Land cover } & Area $(\%)$ & t/ha/year & $\begin{array}{l}\text { Soil loss } \\
\text { t/year (in millions) }\end{array}$ \\
\hline Cropland & 13.1 & 42 & 672 \\
$\begin{array}{l}\text { Perennial crops } \\
\text { Grazing and browsing land }\end{array}$ & 17 & 8 & 17 \\
$\begin{array}{l}\text { Currently unproductive } \\
\text { cropland) }\end{array}$ & 51 & 5 & 312 \\
Currently uncultivable & 3.8 & 70 & 325 \\
Forests & & & \\
Wood and bushland & 18.7 & 5 & 114 \\
Country total & 3.6 & 1 & 4 \\
\hline
\end{tabular}

Source: Hurni 1988.

Table 2 Farm fragmentation in Ethiopia

\begin{tabular}{|c|c|c|}
\hline Number of plots per farm & Number of farmers $(\%)$ & Average size per plot (Ha) \\
\hline One plot & 44 & 0.34 \\
\hline Two plots & 23 & 0.37 \\
\hline Three plots & 13 & 0.36 \\
\hline More than 3 & 20 & 0.33 \\
\hline More than 4 & 11 & 0.32 \\
\hline Average number of plots $=2.3$ & 50 & 0.35 \\
\hline Total $(\mathrm{N})$ & 4589 & \\
\hline
\end{tabular}

Source: Samuel 2005 